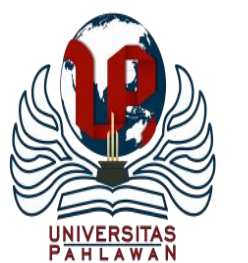

Edukatif : Jurnal Ilmu Pendidikan Volume 3 Nomor 3 Tahun 2021 Halm 951 - 962 EDUKATIF: JURNAL ILMU PENDIDIKAN

Research \& Learning in Education

https:/ledukatif.org/index.php/edukatif/index

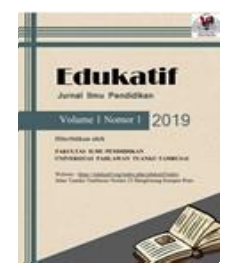

\title{
Pengembangan Bahan Ajar Buku Saku Digital Berbasis Problem Based Learning Pada Mata Pelajaran Ekonomi
}

\author{
Mochammad Chairudin ${ }^{1 凶}$, Retno Mustika Dewi ${ }^{2}$ \\ Program Studi Pendidikan Ekonomi, Universitas Negeri Surabaya, Indonesia ${ }^{1,2}$ \\ E-mail : $\underline{\text { mochammad.17080554076@ mhs.unesa.ac.id }}^{1}$, retnomustika@ unesa.ac.id $^{2}$
}

\begin{abstract}
Abstrak
Ketidakefektivan bahan ajar akan menjadikan kegiatan pembelajaran tidak bermakna. Penelitian pengembangan bahan ajar buku saku digital berbasis Problem Based Learning pada mata pelajaran ekonomi bertujuan untuk mendeskripsikan tingkat kelayakan, menganalisis keefektifan, Serta menjelaskan kepraktisan buku saku digital. Jenis penelitian R\&D (Research and Development) dengan model ADDIE oleh Dick \& Carry dengan lima tahapan pengembangan yaitu analisis, desain, pengembangan, implementasi dan evaluasi. Teknik analisis data berupa 1) analisis dan validasi ahli, 2) perhitungan Pretest-posttest, dan 3) angket respon peserta didik. Hasil penelitian menunjukkan persentase validasi kelayakan buku saku digital sebesar 79,43\% dengan kategori "Layak". Sedangkan skor keefektifan diperoleh persentase 74,4\% dengan kategori "Baik". Serta skor kepraktisan diperoleh persentase 95,5\% dengan kategori "sangat baik". Berdasarkan hasil penelitian, bahan ajar buku saku digital berbasis PBL dinyatakan layak untuk digunakan dalam pembelajaran. Tingkat pemahaman peserta didik terhadap materi APBN dan APBD mengalami peningkatan melalui pemecahan masalah serta keaktifan peserta didik pula mengalami peningkatan melalui diskusi kelompok.
\end{abstract}

Kata Kunci: Pengembangan, Buku Saku Digital, Problem Based Learning, Ekonomi.

\begin{abstract}
The ineffectiveness of teaching materials leads the learning activities become meaningless. The research on the development of digital pocket book as teaching materials based on Problem Based Learning on economic subjects aims to describe the level of feasibility, analyze the effectiveness, and explain the practicality of the digital pocket book. The type of this research is $R \& D$ (Research and Development) with the ADDIE model by Dick \& Carry with five stages of development, namely analysis, design, development, implementation and evaluation. Data analysis techniques were 1) expert analysis and validation, 2) pretest-posttest calculations, and 3) student response questionnaires. The results show the percentage of feasibility validation of digital pocket books was $79.43 \%$ with the category "Feasible". Meanwhile, the score for the effectiveness was $74.4 \%$ in the "Good" category. As well as the practicality score obtained a percentage of $95.5 \%$ in the "very good" category. Based on the results of the research, PBL-based digital pocket book teaching materials are declared feasible for use in the learning. The level of students' understanding of the APBN and APBD material has increased through problem solving and the students' activeness has also increased through group discussions. Keyword: Development, Digital Pocket Book, Problem Based Learning, Economics.
\end{abstract}

Copyright (c) 2021 Mochammad Chairudin, Retno Mustika Dewi

$\triangle$ Corresponding author

Email : mochammad.17080554076@mhs.unesa.ac.id ISSN 2656-8063 (Media Cetak)

DOI : httpsdoi.org10.31004edukatif.v3i3.491 ISSN 2656-8071 (Media Online)

Edukatif : Jurnal Ilmu Pendidikan Vol 3 No 3 Tahun 2021 p-ISSN 2656-8063 e-ISSN 2656-8071 
952 Pengembangan Bahan Ajar Buku Saku Digital Berbasis Problem Based Learning Pada Mata Pelajaran Ekonomi-Mochammad Chairudin, Retno Mustika Dewi

DOI: httpsdoi.org10.31004edukatif.v3i3.491

\section{PENDAHULUAN}

Salah satu aspek penting dalam menentukan kemajuan sebuah negara di dunia adalah bidang pendidikan. Pendidikan memiliki posisi strategis dalam konteks pembangunan karena pendidikan sebagai usaha sadar dalam mencerdaskan bangsa dan pengembangan manusia seutuhnya. Seperti yang tertera pada alenia ke-empat Undang-undang dasar sekaligus menjadi tujuan negara dibidang pendidikan yaitu mencerdaskan kehidupan bangsa. Hal tersebut tertera dalam alenia keempat Pembukaan Undang-Undang Dasar Negara Republik Indonesia Tahun 1945(Indonesia, n.d.). Sehingga bangsa perlunya mengutamakan bidang pendidikan untuk ditingkatkan kualitasnya guna melahirkan masyarakat yang melek pendidikan. Masalah ketertinggalan kualitas pendidikan di Indonesia masih dibawah negara-negara kawasan Asia lainnya (Aini, 2013). Serta diperkuat kembali dalam survei Political And Economic Risk Consultan, bahwa mutu pendidikan Indonesia terletak diurutan ke-12 negara di Asia(Mudlofir, 2013). Permasalahan mutu pengajar salah satu penyebabnya. Kualitas pengajar yang rendah mengakibatkan menurunnya motivasi belajar peserta didik. Kegiatan pembelajaran yang kurang menarik dan tidak berguna secara langsung akan mempengaruhi kemampuan literasi peserta didik(Pertiwi \& Rusyda Firdausi, 2019). Terlebih belum adanya pembaharuan keilmuan dalam bidang elektronik sesuai tuntutan zaman era digital. Hal ini terjadi di SMA Negeri 16 Surabaya dimana bahan ajar Lembar Kerja Siswa (LKS) yang paling sering digunakan di Sekolah. Serta guru menggunakan Software microsoft power point dalam membantunya menyampaikan materi. Walaupun dalam penggunaan power point yang berisi inti-inti materi namun hal ini kurang menarik minat peserta didik untuk membukanya. Disisi lain bahan ajar Lembar Kerja Siswa kurang efisien dibawa peserta didik kemana-mana. Sehingga bahan ajar ini hanya sering digunakan peserta didik sewaktu di sekolah dan dirumah saja. Fenomena yang ditemukan peneliti dalam melaksanakan kegiatan mengajar di kelas XI IPS 1 bahwa masih banyak peserta didik yang masih terpaku dengan isi materi yang ada didalam LKS yang cenderung monoton. Hal ini menjadikan kemampuan berpikir kritis peserta didik belum berkembang.

Upaya dalam meningkatkan kualitas pendidikan perlunya perhatian pada proses belajar peserta didik. Pemanfaatan dan pengaplikasian teknologi dalam kegiatan pembelajaran dapat memaksimalkan proses belajar peserta didik. Peningkatan proses belajar perlu disesuaikan standar pada peserta didik yang didukung dengan teknologi sehingga bahan ajar sebagai alat bantu yeng efektif untuk mencapaai tujuan pembelajaran (Suryani, 2016). Penerapan standar siswa akan mendorong pertumbuhan untuk memenuhi kebutuhan perkembangan sosial abad ke-21 serta akan meningkatkan keterampilan guru, administrator pendidikan dan kualitas pelatih, dan mempromosikan pengembangan profesional guru(Alamin, Shaoqing, \& Le, 2015). Serta diperkuat kembali oleh Kurniawan(2016) bahwa dukungan semua unsur pendidikan secara maksimal dapat memperbaiki mutu pembelajaran. Sehingga pemanfaatan teknologi dalam pendidikan sangat penting bagi pendidik dalam menciptakan bahan ajar yang praktis serta mudah diterima peserta didik untuk belajar secara mandiri sesuai dengan kemampuan dan keiinginanya karena pengguna dapat mengontrol belajarnya(Ruhiat, 2019). Bahan ajar dikembangkan berdasarkan ciri khas dan kebutuhan peserta didik dalam kegiatan pembelajaran.

Bentuk inovasi bahan ajar yang memiliki peranan pokok dalam menciptakan kegiatan belajar yang menarik serta dapat membangkitkan minat belajar peserta didik. Salah satu pemanfaatan perkembangan teknologi dalam dunia pendidikan saat ini yaitu aplikasi buku saku digital berbasis Problem Based Learning yang terdapat pada bagian diskusi dengan dua tipe soal yang berbeda dengan dilengkapi pembasahan serta materi untuk menunjang peserta didik menjawab permasalahan pada bagian diskusi. Aplikasi ini juga dilengkapi dengan latihan soal dari level kongnitif C2 sampai tingkatan HoTS untuk membantu belajar peserta didik. Pengoperasianya yang mudah digunakan serta sistem aplikasi yang tidak banyak menghabiskan ruang internal menjadikan aplikasi ini memiliki kelebihan tersendiri dalam membantu belajar peserta didik baik di Sekolah maupun diluar lingkungan sekolah. Aplikasi belajar yang bisa diinstal di android peserta didik ini 
menjadikannya praktis untuk dibawa dan dibuka dimana saja tidak seperti halnya LKS, yang memiliki bentuk besar, menjadikan LKS sebagai bahan ajar yang digunakan peserta didik di sekolah dan dirumah saja. Mengingat pesatnya perkembangan teknologi, sehingga menjadi alasan peneliti dalam pembuatan bahan ajar berbasis teknologi dengan judul penelitian "Pengembangan bahan ajar buku saku digital berbasis Problem Based Leraning pada mata pelajaran ekonomi." Bahan ajar berupa buku saku digital dengan batasan materi APBN dan APBD yang memiliki fungsi sebagai sarana dan alat pembelajaran guna mempermudahkan proses belajar peserta didik. Tujuan penelitian untuk mendiskripsikan proses pengembangan bahan ajar buku saku digital berbasis Problem Based Learning pada mata pelajaran ekonomi, mendiskripsikan validitas bahan ajar buku saku digital berbasis Problem Based Learning pada mata pelajaran ekonomi, mendiskripsikan keefektifan bahan ajar buku saku digital berbasis Problem Based Learning pada mata pelajaran ekonomi, serta mendiskripsikan kepraktisan bahan ajar buku saku digital berbasis Problem Based Learning pada mata pelajaran ekonomi.

Pengembangan dapat berguna untuk berbagai hal, termasuk dalam bidang pendidikan. Pengembangan merupakan bentuk langkah-langkah dalam mengembangkan suatu produk yang sudah ada serta dapat dipertanggung jawabkan(Irawan \& Suryo, 2017). Penelitian pengembangan ini dilatarbelakangi adanya masalah dalam perangkat pembelajaran yang kurang tepat dari hasil pengamatan peneliti selama mengajar. Bahan ajar merupakan segala bentuk bahan yang digunakan untuk membantu guru dalam melaksanakan kegiatan belajar mengajar di kelas(Nurdyansyah \& Nahdliyah Mutala'liah, 2018). Bahan ajar diartikan juga sebagai alat informasi yang digunakan guru dalam membantunya dalam mengimplementasikan pembelajaran. Buku saku adalah tiruan dari modul yang ukurannya kecil yang praktis untuk dibawa dan digunakan oleh penggunannya(Cahyono, 2018). Bahan ajar dalam bentuk buku saku dapat dijadikan salah satu alternatif bahan ajar yang inovatif dan menarik. Model pembelajaran Problem Based Learning adalah model belajar yang mana peserta didik belajar berdasarkan permasalahan yang sedang terjadi dikehidupan masyarakat dan tidak terpecahkan guna meningkatkan kemampuan berpikir kritis peserta didik(Pilon, 2005). Kemampuan berpikir kritis tidak begitu saja pembawaan dari seseorang dilahirkan. Akan tetapi kemampuan berpikir kritis dapat dikembang seseorang melalui pengalaman menghadapi dan memecahkan permasalahan.

Menurut Mustofa (2016) bahwa bahan ajar lembar kerja siswa dengan model Discovery Learning mampu mengembangkan keterampilan dalam belajar dan pemecahan masalah. Namun berdasarkan pengamatan peneliti pada saat pengenalan lapangan persekolahan, hasil ulangan harian diperoleh nilai ratarata 73,5 termasuk kategori kurang memuaskan. Hal ini dikarenakan kecenderungan penggunaan bahan ajar Lembar Kerja Siswa yang terpaku pada materi saja serta metode penyampaian materi berupa ceramah menyebabkan peserta didik kurang aktif serta kemampuan berpikir kritis tidak berkembang karena peserta didik tidak diberikan kesempatan mengembangkan pola pikirnya. Keterbatasan waktu belajar secara online dikarenakan pandemi Covid-19 sehingga peserta didik hanya dituntut memahami materi melalui merangkum materi dari lembar kerja siswa. Sehingga hal ini terjadi kesenjangan yang seharusnya kegiatan pembelajaran sebagai usaha mengembangkan pola pikir peserta didik namun berlainan sekali dengan rendahnya keterampilan belajar peserta didik. Sehingga hal ini menarik minat peneliti untuk mengembangkan bahan ajar buku saku digital berbasis Problem Based Learning yang praktis digunakan serta melatih kemampuan berpikir kritis peserta didik dalam pembelajaran diwaktu pandemi Covid-19. Hal ini dikarenakan kemampuan tersebut dapat dikembangkan melalui pengalaman menyelesaikan masalah(Nafiah \& Suyanto, 2014).

\section{METODE}

Bentuk penelitian ini yaitu penelitian pengembangan atau Research and Development $(R \& D)$. Penelitian dan pengembangan digunakan untuk menghasilkan produk aplikasi dan menguji keefektifannya. Model pengembangan yang digunakan peneliti adalah model ADDIE (Analysis-Design-Develop-ImplementationEvaluation)(Huda, 2017). Subjek penelitian berupa peserta didik kelas XI IPS 1 SMA Negeri 16 Surabaya 
dengan jumlah 20 orang. dilaksanakan secara daring karena pandemi Covid-19. Sebelum dilakukan implementasi produk, terlebih dahulu peserta didik dibagikan soal-soal Pretest melalui Google Form untuk mengetahui tingkat pemahaman awal. Kemudian pengaplikasian buku saku digital dalam kegiatan pembelajaran setelah itu dilakukan Posttest diakhir pembelajaran.

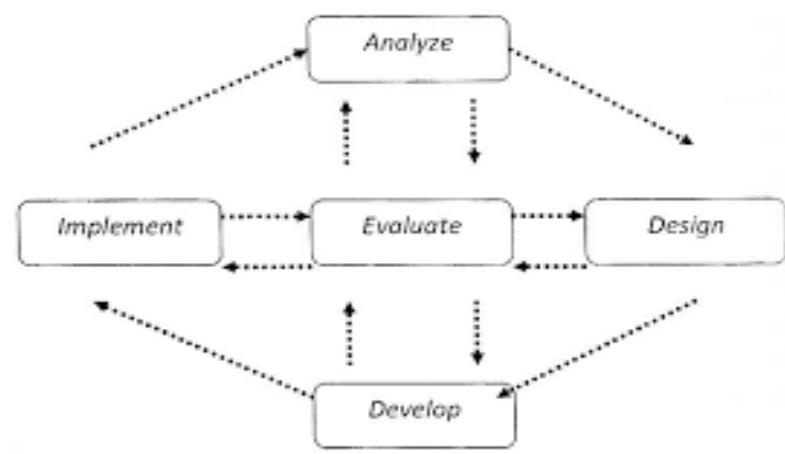

Gambar 1. Model pengembangan ADDIE

Peneliti menggunakan desain one-group pretest-posttest design(Sugiyono, 2016) dengan mengukur hasil belajar.

Tabel 1

One-group Pretest-Posttest Design.

Keterangan :

\begin{tabular}{|c|c|c|c|}
\hline Kelompok & Pretest & Perlakuan & Posttest \\
\hline $\begin{array}{c}\text { K. } \\
\text { Eksperimen }\end{array}$ & O1 & X & O2 \\
\hline
\end{tabular}

O1 : Pretest sebelum uji coba

$\mathbf{X} \quad$ : Implementasi produk.

O2 : Posttest setelah uji coba.

Teknik analisis data berupa teknik analisis deskriptif kualitatif dan kuantitatif. (1) Analisis deskriptif kualitatif melalui saran dan masukan yang diberikan para penelaah sebagai bahan perbaikan dan penyempurnaan. (2) Analisis kuantitatif meliputi angket validator, angket respon peserta didik, serta penilaian hasil belajar.

Besarnya tingkat kelayakan dari buku saku digital dapat dihitung dengan rumus:

Presentase $=\frac{\text { Jumlah skor }}{\text { Skor maksimal }} \times 100 \%$

Tabel 2

Krieria Validasi

\begin{tabular}{|l|l|l|}
\hline No. & Persentase & Keterangan \\
\hline 1. & $81 \%-100 \%$ & Sangat Valid \\
\hline 2. & $61 \%-80 \%$ & Valid \\
\hline 3. & $41 \%-60 \%$ & Kurang Valid \\
\hline 4. & $21 \%-40 \%$ & Tidak Valid \\
\hline 5. & $00 \%-20 \%$ & SangatTidak Valid \\
\hline
\end{tabular}

Adapun tingkat keefektifan buku saku digital diperoleh dari hasil belajar peserta didik sebelum dan sesudah menggunakan buku saku digital dapat diketahui dengan rumus;

$$
N \text {-gain }=\frac{X \text { Postesr }-X \text { Pretest }}{\text { Xmaximal }-X \text { Pretest }} \times 100 \%
$$




\section{Keterangan :}

Xpost $=$ nilai posttest

Xpre $=$ nilai pretest

$\mathrm{Xmax}=$ Nilai Maksimal dari pretest dan posttest

Sedangkan untuk mengukur kepraktisan buku saku digital digunakan lembar analisis respon peserta didik. Pilihan jawaban yang terdapat pada lembar respon meliputi jawaban "Ya" dan "Tidak". Hasil dari angket respon peserta didik kemudian dianalisis dengan menggunakan metode deskriptif kuantitatif dengan langkah-langkah sebagai berikut:

Tabulasi data respon peserta didik dengan menggunakan skala Guttman seperti yang tertera pada tabel 3 (Riduwan, 2013).

\section{Tabel 3}

\section{Kriteria skor angket respon}

\begin{tabular}{|l|l|}
\hline Jawaban & Skor \\
\hline Ya & 1 \\
\hline Tidak & 0 \\
\hline
\end{tabular}

Rumus untuk menghitung persentase respon positif peserta didik yaitu;

$$
\text { Persent }=\frac{\text { Jmlh respon positif }}{\text { Jmlh nilai negatif }} \times 100 \%
$$

Mengonversi perolehan nilai untuk dijadikan nilai kualitatif sesuai dengan kriteria penilaian pada tabel 4 (Riduwan, 2013).

\section{Tabel 4}

Kriteria Angket Respon peserta didik

\begin{tabular}{|l|l|}
\hline Rentang Persentase (\%) & Kategori \\
\hline $0-20$ & Tidak Baik \\
\hline $21-40$ & Kurang Baik \\
\hline $41-60$ & Cukup Baik \\
\hline $61-80$ & Baik \\
\hline $81-100$ & Sangat Baik \\
\hline
\end{tabular}

Berdasarkan dari hasil penilaian tersebut, bahan ajar buku saku digital dinyatakaan efektif apabila persentase respon peserta didik $\geq 61 \%$.

\section{HASIL DAN PEMBAHASAN}

Hasil pengembangan bahan ajar buku saku digital berbasis Problem Based Learning pada mata pelajaran ekonomi. Adapun Software yang digunakan pada proses pengembangan bahan ajar yaitu sebagai berikut. 1) Corel Draw X5 yang digunakan untuk desain buku saku digital. 2) Flip Book yang digunakan untuk mengintegrasikan setiap halaman menjadi layaknya buku dan dapat disimpan berupa situs web. 3) Web2apk digunakan untuk mengkonversi data berupa situs web kedalam bentuk file Apk.

Model pengembangan pada penelitian ini yaitu model ADDIE dengan lima tahapan yaitu; Analisys, design, development, implementation, dan evaluation (Sugiyono, 2016).

Tahap Analisis (Analysis). Pada tahap ini diperoleh masalah dalam penggunaan bahan ajar yang cenderung menggunakan LKS dan buku paket dengan metode ceramah guru dalam menyampaikan materinya. Serta karakteristik peserta didik dalam kegiatan pembelajaran yang cenderung kurang aktif secara individu dan perlunya stimulus dari guru untuk meningkatkan keaktifan peserta didik. Sehingga peserta didik kurang mendapat kesempatan untuk mengembangkan pola pikirnya dalam belajar menyelesaikan masalah yang dihubungkan dengan konteks kehidupan. Serta berbasis Problem Based Learning diharapkan mampu 
meningkatkan kemampuan berpikir kritis peserta didik melalui penyelesaian masalah dengan konteks kehidupan. Analisis materi dalam buku saku digital berbasis problem based learning yaitu APBN dan APBD dalam pembangunan ekonomi. Materi ini cocok dibuat buku saku digital berbasis problem based learning mengingat pada materi ini mengandung banyak hafalan dan diharapkan mampu memberikan kemudahan belajar kepada peserta didik melalui studi kasus.

Tahap Perancangan (Design). Berdasarkan analisis masalah dan kebutuhan peserta didik, dilaksanakan perancangan buku saku digital yang meliputi penggunaan software Corel Draw X5 untuk membuat desain cover dan background aplikasi. Sedangkan untuk penyusunan draft bahan ajar digunakan software flip book meliputi (Pendahuluan; Kata pengantar, Daftar Isi, KI dan KD), (Isi; materi, soal latihan berbasis Problem Based Learning, kunci jawaban), (Bagian Penunjang; Daftar Pustaka dan tentang penulis). Terakhir dengan Software web2apk untuk mengekstrak menjadi sebuah aplikasi.

Tahap Pengembangan (Development). Pada tahap ini dilakukan pengujian pertama dalam mengetahui tingkat kelayakan buku saku digital oleh tim ahli baik media, materi dan evaluasi. Adapun tahapan dalam pengembangan pertama pada produk meliputi; review, revisi dan validasi. Bahan ajar buku saku digital ditelaah dan divalidasi oleh dosen jurusan pendidikan ekonomi meliputi validator ahli materi, media dan evaluasi.

\section{Tabel 5}

Saran ahli

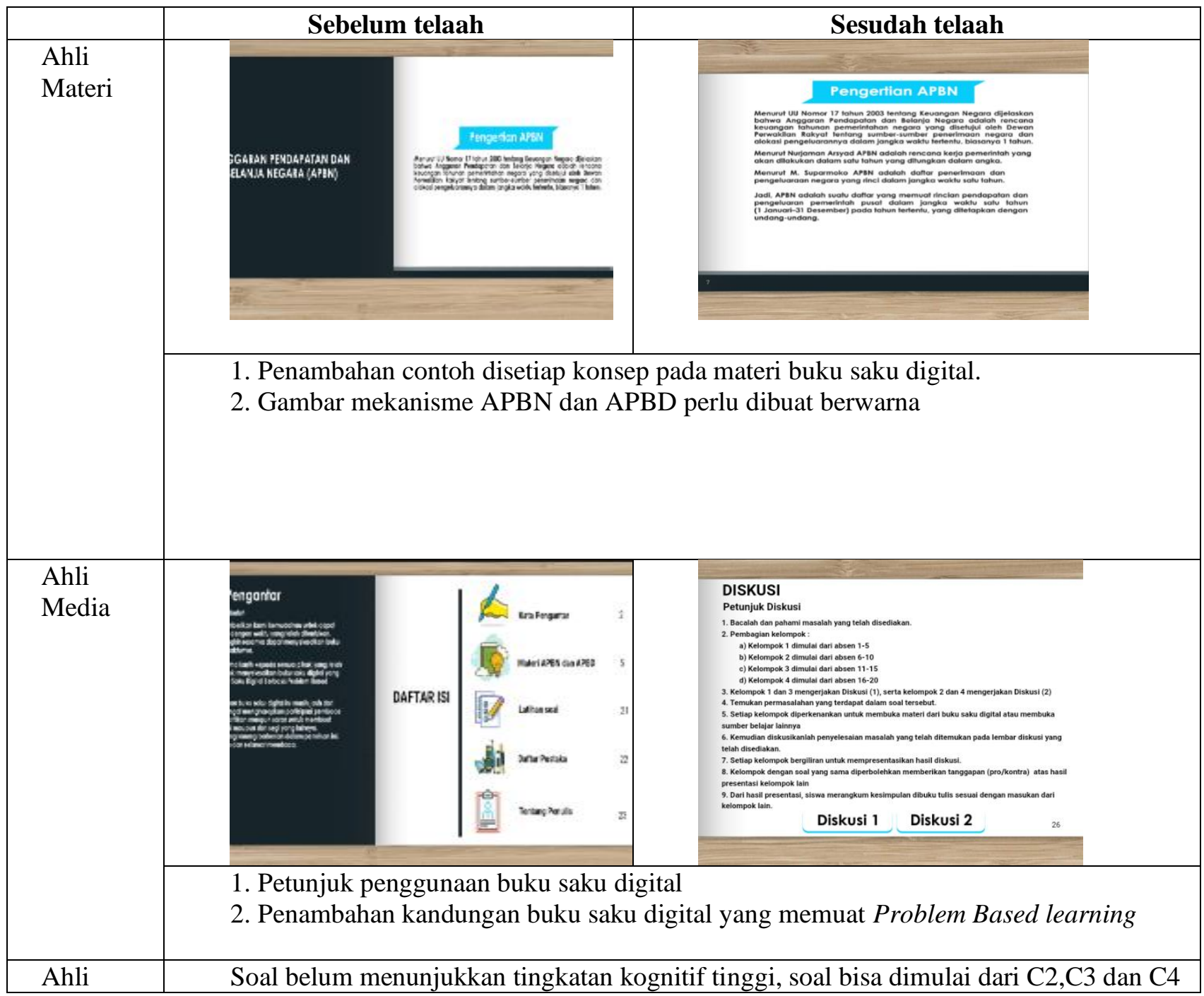




\begin{tabular}{|c|c|c|}
\hline \multirow{2}{*}{ Evaluasi } & & \\
\hline & $\begin{array}{l}\text { Apabila realisasi pengeluaran } \\
\text { negara lebih besar daripada } \\
\text { penerimaan negara, artinya } \\
\text { pemerintah menjalankan kebijakan } \\
\text { anggaran.... } \\
\text { A. Seimbang } \\
\text { B. Surplus } \\
\text { C. Tetap } \\
\text { D. Dinamis } \\
\text { E. Defisit }\end{array}$ & $\begin{array}{l}\text { Pada saat ini seringkali terjadi bencana alam } \\
\text { dibeberapa daerah di Indonesia. Akibatnya } \\
\text { banyak sarana prasarana yang rusak yang } \\
\text { berimbas pada kegiatan ekonomi diwilayah } \\
\text { tersebut mengalami penurunan. Bagaimana } \\
\text { upaya pemerintah melalui APBN dalam } \\
\text { menopang dan mengatasi masalah } \\
\text { tersebut.... } \\
\text { A. Pemerintah memanfaatkan DBH untuk } \\
\text { mendanai kebutuhan daerah } \\
\text { B. Pemberian dana darurat bagi daerah } \\
\text { terdampak bencana. } \\
\text { C. Pemerintah mencari pinjaman dana } \\
\text { kepada daerah lain } \\
\text { D. Pemanfaatan dana otonomi khusus untuk } \\
\text { memenuhi kebutuhan daerah } \\
\text { E. Memanfaatkan Dana alokasi umum } \\
\text { daerah }\end{array}$ \\
\hline
\end{tabular}

Sumber: https://quizizz.com/admin/quiz/5d9eae41ca81dc001a06e2ff/apbn-apbd-dan-kebijakan-fiskal

Tahap Implementasi (Implementation) . Pada tahap ini produk yang telah dirancang dan dikembangkan kemudian diimplementasikan terbatas pada peserta didik XI IPS 1 SMA Negeri 16 Surabaya dan dilaksanakan secara daring karena pandemi Covid-19. Sebelum dilakukan implementasi produk, terlebih dahulu peserta didik dibagikan soal-soal Pretest melalui Google Drive untuk mengetahui tingkat pemahaman awal. Kemudian pengaplikasian buku saku digital dalam kegiatan pembelajaran setelah itu dilakukan Posttest diakhir pembelajaran guna mengetahui perubahan dari hasil pemberian perlakuan.

Tahap Evaluasi (Evaluation). Pada tahap ini produk yang telah diimplementasikan kemudian dianalisis kualitas produk berupa penilaian formatif bahan ajar android buku saku digital dan ketercapaian belajar peserta didik. Berdasarkan pada tahap pengembangan diketahui bahwa bahan ajar buku saku digital layak untuk digunakan dengan perbaikan pada beberapa hal sebelum diuji cobakan dalam kegiatan pembelajaran.

Hasil Penelitian selanjutnya dapat dijabarkan sebagai berikut

\section{Telaah Bahan Ajar Buku Saku Digital Berbasis Problem Based Learning Pada Mata Pelajaran Ekonomi}

Buku saku digital berbasis Problem Based Learning pada mata pelajaran ekonomi ditelaah oleh dosen pembimbing untuk mendapatkan saran yang bersifat konstruktif. Adapun saran dari penelaah yaitu Pada bagian telaah materi disarankan 1) Penambahan contoh disetiap konsep pada materi buku saku digital. 2) Gambar mekanisme APBN dan APBD perlu dibuat berwarna. Selanjutnya pada telaah media disarankan 1) Penambahan contoh disetiap konsep pada materi buku saku digital. 2) Gambar mekanisme APBN dan APBD perlu dibuat berwarna. Terakhir saran penelaah evaluasi yaitu perbaikan 1) Soal belum menunjukkan tingkatan kognitif tinggi, soal bisa dimulai dari C2,C3 dan C4. Setelah mendapatkan saran dari dosen pembimbing maka langkah selanjutnya yaitu dilakukan perbaikan bahan ajar yang dikembangkan.

2. Validitas Bahan Ajar Buku Saku Digital Berbasis Problem Based Learning Pada Mata Pelajaran Ekonomi

Analisis tingkat kelayakan buku saku digital berdasarkan hasil validator dosen ahli. Berikut hasil validasi pada tabel 6 .

\section{Tabel 6}

\section{Validasi Buku Saku Digital}


DOI: httpsdoi.org10.31004edukatif.v3i3.491

\begin{tabular}{|l|l|l|}
\hline Aspek & Skor & Keterangan \\
\hline Materi & $80 \%$ & Valid \\
\hline Media & $80 \%$ & Valid \\
\hline Evaluasi & $78,3 \%$ & Valid \\
\hline Rata-rata & $\mathbf{7 9 , 4 3 \%}$ & Valid \\
\hline
\end{tabular}

Pada tabel 5 menjelaskan bahwa validasi dari bahan ajar buku saku digital berbasis problem based learning validasi materi dengan rata-rata skor persentase $80,00 \%$. Validasi bahasa tidak digunakan peneliti disebabkan pada validasi materi sudah mencakup komponen bahasa yang digunakan sesuai dengan ejaan Bahasa Indonesia yang baik dengan memperoleh skor 4 dari validator. Sedangkan pada komponen media diperoleh rata-rata skor persentase sebesar $80,00 \%$. Terakhir validasi evaluasi diperoleh rata-rata skor persentase sebesar 78,3\%. Adapun rata-rata skor validasi pada bahan ajar buku saku digital berbasis Problem Based Learning diperoleh persetase 79,43\%.

3. Keefektifan Bahan Ajar Buku Saku Digital Berbasis Problem Based Learning Pada Mata Pelajaran Ekonomi

Sebelum uji coba buku saku digital, terlebih dahulu peserta didik dengan jumlah 20 orang dibagikan soal Pretest yang dibagikan melalui link pada Google Form berupa soal pilihan ganda sebanyak 10 butir dengan 5 soal diantaranya termasuk dalam kategori HOTS. Soal Pretest-Posttest yang digunakan sebelumnya telah dilakukan telaah dan validasi evaluasi serta sudah disesuakan dengan tingkatan soal berdasarkan Taksonomi Bloom. Hasil Pretest peserta didik diperoleh nilai rata rata 37,5. Setelah dilaksanakan uji coba buku saku digital, selanjutnya dibagikan kembali link soal Posttest untuk mengetahui besarnya perubahan hasil belajar peserta didik. Hasil Posstest peserta didik diperoleh nilai rata-rata sebesar 74,4.

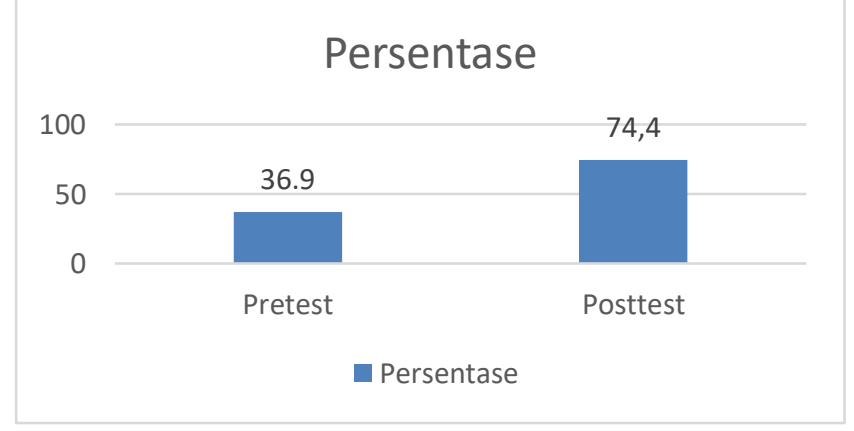

Gambar 2. Pretest-Posttest Peserta didik

Berdasarkan gambar 2. bahwa adanya peningkatan hasil belajar setelah penerapan buku saku digital. Peningkatan hasil belajar tersebut dapat dihitung dengan $n$-gain dan diperoleh nilai sebesar 0,744 dengan kriteria "Baik".

4. Kepraktisan Bahan Ajar Buku Saku Digital Berbasis Problem Based Learning Pada Mata Pelajaran Ekonomi

Uji Kepraktisan bahan ajar buku saku digital yang dibagikan melalui Google Form yang terdiri dari 10 pertanyaan diperoleh hasil pada tabel 7.

Tabel 7

Respon Peserta Didik

\begin{tabular}{|l|l|l|l|}
\hline No. & Komponen & Hasil & Kategori \\
\hline 1. & Syarat Diksktik & $96 \%$ & Sangat Baik \\
\hline
\end{tabular}




\begin{tabular}{|l|l|l|l|}
\hline 2. & Syarat Konstruksi & $96 \%$ & Sangat Baik \\
\hline 3. & Syarat Teknis & $94,60 \%$ & Sangat Baik \\
\hline
\end{tabular}

Respon peserta didik diperoleh rata-rata seluruh komponen memperoleh kategori sangat baik dengan persentase $95,5 \%$ yang meliputi syarat dikdaktik $96 \%$, syarat konstruksi $96 \%$, dan syarat teknis $94,60 \%$.

Pembahasan terhadap hasil penelitian dapat dijabarkan sebagai berikut.

\section{Telaah Bahan Ajar Buku Saku Digital Berbasis Problem Based Learning Pada Mata Pelajaran Ekonomi}

Hasil telaah buku saku digital diperoleh masukan pada telaah materi berupa Saran pertama, penambahan contoh disetiap materi untuk memudahkan peserta didik dalam memahami materi pada buku saku digital. Saran kedua, penggantian gambar mekanisme APBN dan APBD dengan gambar yang berwarna. Hal ini agar mekanisme APBN dan APBD dapat terbaca dengan jelas oleh semua peserta didik secara mandiri termasuk peserta didik yang mengalami gangguan penglihatan (nasional, 2010). Selanjutnya masukan dari penelaah media yaitu pertama, menambah petunjuk penggunaan buku saku digital. Hal ini dimaksudkan agar tujuan dari buku saku digital mudah dipahami oleh peserta didik. Saran kedua, Penambahan kandungan buku saku digital yang memuat Problem Based learning. hal ini dimaksudkan agar bahan ajar benar-benar menunjukkan berbasis model problem based learning dengan pemecahan masalah melalui diskusi. Terakhir masukan dari penelaah evaluasi yaitu penggantian soal-soal pada bagian latihan soal di buku saku digital dengan soal-soal tingkatan kognitif yang dimulai dari c2-c4. Hal ini dimaksudkan agar kognitif peserta didik dapat berkembang dengan bantuan soal-soal dengan tingkatan dari terendah sampai tertinggi.

2. Validitas Bahan Ajar Buku Saku Digital Berbasis Problem Based Learning Pada Mata Pelajaran Ekonomi

Validitas bahan ajar buku saku digital berbasis problem based learning dikatakan valid apabila dalam validasi materi, media dan evaluasi dengan nilai $\geq 61 \%$. Berdasarkan hasil validasi bahan ajar buku saku digital berbasis problem based learning meliputi validasi materi dengan variabel kualitas materi dan tujuan serta kualitas teknis dari buku saku digital dengan rata-rata skor persentase 80,00\% termasuk dalam kategori valid. Selanjutnya hasil validasi ahli media diperoleh rata-rata skor persentase sebesar $80,00 \%$ termasuk dalam kategori valid. Kemudian hasil validasi evaluasi buku saku digital diperoleh rata-rata skor persentase sebesar 78,3\% dan dalam kategori valid. Berdasarkan hasil dari validasi materi, media dan evaluasi dapat dirataratakan sebesar 79,43\% dengan keterangan valid dan layak untuk digunakan dalam kegiatan pembelajaran. Hal ini sejalan dengan penelitian oleh (Septianita, widjianto, \& Hartatiek, 2014) dengan judul pengembangan media belajar buku saku fisika dengan teknologi augmented reality berbasis android pada materi fluida statis untuk siswa kelas X SMA IPA diperoleh nilai rata-rata keseluruhan validasi sebesar 3,41 atau setara dengan 68,2\% dengan keterangan valid. Penelitian lain dilakukan oleh Reza (Reza, 2017) dengan judul pengembangan media pembelajaran dalam bentuk buku saku digital berbasis android materi ajar gerak dan gaya di SMK 1 Kedungwuni diperoleh persentase kelayakan 80,87\% termasuk dalam kategori layak dan efektif untuk digunakan.

\section{Keefektifan Bahan Ajar Buku Saku Digital Berbasis Problem Based Learning Pada Mata Pelajaran Ekonomi}

Penggunaan bahan ajar buku saku digital ini mampu meningkatkan hasil belajar peserta didik yang dapat dilihat dari peningkatan nilai Posttest sebesar 36,9. Akan tetapi pada nilai rata-rata Pretest belum memenuhi ketuntasan klasikal, sedangkan pada nilai rata-rata Posttest peserta didik sudah memenuhi ketuntasan klasikal sebesar 74,4 . Hal dapat dilihat dari jumlah peserta didik yang menjawab benar $\geq 61 \%$ setelah diberikannya perlakuan. Penelitian ini sejalan dengan penelitian dengan judul pengembangan bahan ajar buku saku berbasis problem based learning untuk meningkatkan motivasi dan prestasi belajar akuntansi pada siswa SMA oleh (Fahma, 2018) dengan skor rata-rata motivasi belajar 75,48 yang artinya kelas yang diajarkan dengan buku saku berbasis problem based learning lebih efektif dari pada sebelum diajarkan dengan 
buku saku berbasis problem based learning. Tingkat ketuntasan klasikal diperoleh persentase sebesar 90\% yang artinya sejumlah 18 peserta didik dinyatakan tuntas secara individu dengan 2 sisanya yang tidak tuntas. Peneliti lain dengan judul penggunaan bahan ajar berbasis digital book untuk meningkatkan hasil belajar siswa dalam mata pelajaran matematika pada materi logika matematika oleh (Zaini, 2019) diperoleh skor posttest rata-rata 72,43 lebih tinggi dari skor pretest sebesar 42,16. Artinya penggunaan bahan ajar berbasis digital book sangat efektif digunakan daripada bahan ajar cetak dalam meningkatkan hasil belajar siswa. Terbukti dari peningkatan keaktifan peserta didik melalui pembelajaran yang lebih interaktif dengan penerapan teori belajar yang diterima dalam hal partisipasi peserta didik. Adanya peserta didik yang tidak tuntas dalam tes kemampuan peserta didik disebabkan kurangnya antusias peserta didik tersebut dalam pembelajaran. Penyebab rendahnya prestasi belajar peserta didik adalah motivasi belajar yang rendah pula (Irawan, 2017). Selain faktor tersebut, adanya peserta didik yang mengalami penurunan tes kemampuan peserta didik disebabkan peserta didik tersebut masih kesulitan dalam menemukan konsep dalam pemecahan masalah dalam pembelajaran dengan model Problem Based Learning.

4. Kepraktisan Bahan Ajar Buku Saku Digital Berbasis Problem Based Learning Pada Mata Pelajaran Ekonomi

Hasil analisis dalam penggunaan bahan ajar buku saku digital berbasis problem based learning diperoleh uji kepraktisan dengan skor rata-rata keseluruhan 95,5\% dengan kategori "sangat baik" yang meliputi syarat dikdaktik 96\%, syarat konstruksi $96 \%$ dan syarat teknis $94,60 \%$. Penelitian ini sejalan dengan penelitian (Yaqin, 2016) dengan judul pengembangan buku saku digital berbasis android sebagai pendukung bahan ajar pada materi PPh pasal 21 berdasarkan uji kepraktisan melalui angket respon peserta didik diperoleh skor rata-rata 95\% dengan kriteria sangat baik yang artinya buku saku digital berbasis android mendapat respon sangat baik bagi peserta didik. Kemampuan berinteraksi dan kerjasama peserta didik mengalami peningkatan dikarenakan proses pembelajaran berbasis problem based learning mengharuskan peserta didik untuk saling berkomunikasi dan berinteraksi dengan kelompok untuk memecahkan permasalahan. Setiap anggota kelompok saling berdiskusi dalam menemukan alternatif jawaban dari permasalahan yang telah disediakan pada buku saku digital. Artinya semua anggota kelompok tidak ada yang pasif dalam diskusi kelompok. Selanjutnya dalam presentasi hasil pemecahan masalah setiap kelompok secara bergantian memaparkan hasil kerja kelompok serta diberikan kesempatan kepada kelompok lain untuk memberikan tanggapan dari apa yang telah dipresentasikan perwakilan kelompok penyaji. Sehingga hal ini tercipta kominakasi intern dan ekstern kelompok. Kemampuan peserta didik dalam memahami materi juga mengalami peningkatan yang didapat dilihat dari peningkatan hasil belajar sebesar 36,9 dari skor rata-rata nilai pretest 37,5 dan skor rata-rata postest sebesar 74,4. Hal ini berdasarkan saran dan masukan dari peserta didik yang meliputi materi yang mudah dimengerti, menggunakan buku saku digital dapat membangkitkan motivasi belajar dan menggunakan buku saku digital ini peserta didik dibimbing untuk berpikir kritis serta melibatkan fenomena-fenomena dalam kehidupan sehari-hari. Sejalan dengan penelitian (Haque \& Kurniawan, 2020) dengan judul pengembangan bahan ajar ekonomi menggunakan Unity 3D dalam bentuk buku saku digital berbasis problem based learning dengan rata-rata skor uji kepraktisan sebesar $88 \%$ dengan kategori "sangat baik".

Berdasarkan pengamatan peneliti dalam kegiatan pembelajaran dengan menggunakan bahan ajar buku saku digital berbasis Problem Based Learning terlihat tingkat keaktifan peserta didik mengalami peningkatan. Hal ini dikarenakan setiap anggota kelompok memilik tugas masing-masing dan bertanggung jawab untuk menyelesaikan permasalahan yang telah dibagi oleh kelompoknya serta mempresentasikannya. Berdasarkan pembagian tugas tersebut setiap peserta didik tidak sekedar menjawab pertanyaan yang diberikan. Akan tetapi setiap peserta didik diberikan kesempataan dalam memahami materi secara mandiri dengan penalarannya. Peningkatan keaktifan setiap peserta didik terbukti ketika ada tanggapan dari kelompok lain teman satu kelompoknya saling bergantian menjawab pertanyaan tersebut. Sehingga hal ini tercipta kerjasama pada 
961 Pengembangan Bahan Ajar Buku Saku Digital Berbasis Problem Based Learning Pada Mata Pelajaran Ekonomi-Mochammad Chairudin, Retno Mustika Dewi

DOI: httpsdoi.org10.31004edukatif.v3i3.491

internal kelompok serta peningkatan keaktifan pada setiap peserta didik dalam penyajian hasil pemecahan masalah dan saling memberikan tanggapan pada kelompok penyaji. Namun, soal-soal yang disedikan peneliti hanya terbatas sehingga jawaban antar kelompok kebanyakan hampir sama sehingga setiap penyaji saling melengkapi tim penyaji yang lainnya. Sehingga harapannya dengan model Problem Based Learning dapat diterapkan pendidik dalam kegiatan pembelajaran pada kelas lain serta memperbanyak bank soal berbasis pemecahan masalah.

\section{KESIMPULAN}

Berdasarkan hasil penelitian, dapat disimpulkan bahwa penggunaan bahan ajar buku saku digital berbasis Problem Based Learning mempunyai pengaruh signifikan dalam upaya meningkatkan kemampuan kognitif dan keaktifan peserta dilihat dari keterampilan memecahkan permasalahan serta dalam memberikan tanggapan terhadap kelompok lain.

\section{DAFTAR PUSTAKA}

Aini, S. shinta qurrrota' \& S. (2013). Pocketbook As Media Of Learning To Improve Students' Learning Motivation. Akuntansi, Jurnal Pendidikan Xi, Vol, XI(2), 68-75.

Alamin, A. A., Shaoqing, G., \& Le, Z. (2015). The development of educational technology policies (19962012) lessons from China and the USA. International Education Studies, 8(6), 142-150. https://doi.org/10.5539/ies.v8n6p142

Cahyono, B. D. falasifa tsani; A. eahma. (2018). pengembangan bahan ajar buku saku matematika berbasis pendidikan karakter materi trigonometri. Phenomenon, 8 (2), 185-199. Retrieved from https://journal.walisongo.ac.id/index.php/Phenomenon/article/view/2929

Fahma, N. (2018). Pengembangan Bahan Ajar Buku Saku Berbasis Problem Based Learning Untuk Meningkatkan Motivasi Dan Prestasi Belajar Akuntansi Pada Siswa SMA. Universitas Sebelas Maret.

Haque, Z. U., \& Kurniawan, R. Y. (2020). Pengembangan Bahan Ajar Ekonomi Menggunakan Unity 3D Dalam Bentuk Buku Saku Digital Berbasis Problem Based Learning. International Journal of Social Sciences \& Educational Studies, Vol. $20(\mathrm{Xx}), 1-11$.

Huda, F. A. (2017). Macam-macam dan jenis penelitian pengembangan. Ratkhan.Web.Id, 1. Retrieved from https://fatkhan.web.id/macam-macam-dan-jenis-penelitian-pengembangan/

Indonesia. Pembukaan Undang-Undang Dasar Negara Republik Indonesia Tahun 1945.

Irawan, E., \& Suryo, T. (2017). Implikasi multimedia interaktif berbasis flash terhadap motivasi dan prestasi belajar matematika. 10(1), 33-50.

Kurniawan, R. Y. (2016). Identifikasi Permasalahan Pendidikan Di Indonesia Untuk Meningkatkan Mutu Dan Profesionlisme Guru. Konvensi Nasional Pendidikan Indonesia (KONASPI) VIII Tahun, (October 2016), 13-17. Retrieved from https://www.researchgate.net/publication/317184069\%0AIDENTIFIKASI

Mudlofir, A. (2013). Pendidikan Karakter: Konsep dan Aktualisasinya dalam Sistem Pendidikan Islam. Nadwa | Jurnal Pendidikan Islam Vol. 7, Nomor 2,Oktober 2013, 7. Retrieved from http://journal.walisongo.ac.id/index.php/nadwa

Mustofa, A. (2016). pengembangan lembar kerja siswa berbasis model pembelajaran discovery learning pada mata submateri sifat-sifat cahaya untuk meningkatkan kemampuan literasi sains siswa. In jurnal penelitian pendidikan IPA.

Nafiah, Y. N., \& Suyanto, W. (2014). Penerapan model problem-based learning untuk meningkatkan keterampilan berpikir kritis dan hasil belajar siswa. Jurnal Pendidikan Vokasi, 4(1), 125-143. https://doi.org/10.21831/jpv.v4i1.2540 
962 Pengembangan Bahan Ajar Buku Saku Digital Berbasis Problem Based Learning Pada Mata Pelajaran Ekonomi-Mochammad Chairudin, Retno Mustika Dewi

DOI: httpsdoi.org10.31004edukatif.v3i3.491

Nurdyansyah \& Nahdliyah Mutala'liah. (2018). PengembanganBahan AjarModul Ilmu Pengetahuan Alambagi Siswa Kelas Iv Sekolah Dasar. 1-10. Retrieved from http://eprints.umsida.ac.id/id/eprint/1607

Pertiwi, U. D., \& Rusyda Firdausi, U. Y. (2019). Upaya Meningkatkan Literasi Sains Melalui Pembelajaran Berbasis Etnosains. Indonesian Journal of Natural Science Education (IJNSE), 2(1), 120-124. https://doi.org/10.31002/nse.v2i1.476

Pilon, S. G. B. van H. B. van R. (2005). Teaching language technology at the North-West University. University of WAshington, (June), 57. https://doi.org/10.3115/1627291.1627304

Ruhiat, Y. \& I. D. (2019). Pengembangan Bahan Ajar Digital pada Mata Pelajaran Dasar Listrik dan Elektronika Kelas X. Jurnal Teknologi Pendidikan Dan Pembelajaran, (November), 156-168.

Sugiyono. (2016). Metode Penelitian Kuantitatif, Kualitatif, dan R\&D. Bandung: Alfabeta.

Suryani, N. (2016). Pengembangan media pembelajaran sejarah berbasis it. Jurnal Sejarah Dan Budaya, 10, 186-195.

Yaqin, A. R. (2016). Pengembangan Buku Saku Digital Berbasis Android Sebagai Pendukung Bahan Ajar Pada Materi Pph Pasal 21. Jurnal Pendidikan Akuntansi (JPAK), 5(1).

Zaini, H. D. D. H. H. (2019). penggunaan bahan ajar berbasis digital book untuk meningkatkan hasil belajar siswa dalam mata pelajaran matematika pada materi logika matematika. JTEP-Jurnal Teknologi Pendidikan Dan Pembelajaran, 4, 816-825. 